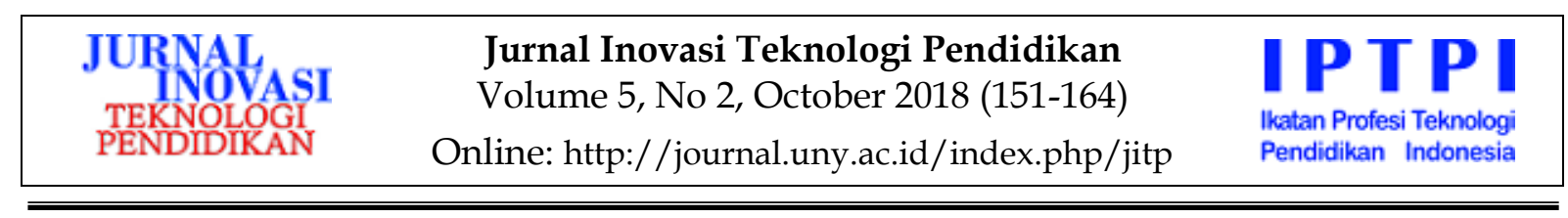

\title{
PENGEMBANGAN MULTIMEDIA PEMBELAJARAN BERBASIS ROLE PLAYING GAMES (RPG) PADA MATERI LINGKARAN UNTUK SISWA SMP/MTs KELAS VIII
}

\author{
Hilyatush Shofa ${ }^{*}$, Herman Dwi Surjono ${ }^{2}$ \\ 1Pusat Pendidikan Pelatihan Kemenristekdikti, 2Universitas Negeri Yogyakarta \\ ${ }^{1}$ Muncul, Setu, Muncul, Setu, Kota Tangerang Selatan, Banten 15314, Indonesia \\ 2J1. Colombo No. 1, Depok, Sleman 55281, Yogyakarta, Indonesia \\ * Corresponding Author. Email: hilyatushshofa@gmail.com
}

\begin{abstract}
Abstrak
Penelitian ini bertujuan: (1) menghasilkan produk multimedia pembelajaran berbasis RPG pada materi lingkaran untuk siswa SMP/MTs Kelas VIII yang layak digunakan dalam proses pembelajaran, (2) mengetahui efektivitas produk tersebut dalam meningkatkan pemahaman konsep, dan (3) mengetahui efektivitas produk tersebut dalam meningkatkan motivasi belajar. Penelitian pengembangan ini mengacu pada langkah-langkah yang dikembangkan oleh Alessi \& Trollip yang meliputi tiga tahap: perencanaan, perancangan, dan pengembangan. Pada keseluruhan tahap tersebut, evaluasi berkelanjutan dilaksanakan untuk memantau kualitas produk yang dikembangkan. Hasil penelitian menunjukkan bahwa: (1) produk multimedia pembelajaran berbasis RPG pada materi lingkaran untuk siswa SMP/MTs Kelas VIII dinyatakan layak digunakan dalam proses pembelajaran berdasarkan penilaian sangat baikyang diberikan oleh ahli materi dan ahli media, serta respon sangat positif yang diberikan oleh siswa; (2) produk tersebut efektif dalam meningkatkan pemahaman konsep, berdasarkan perolehan nilai gain sebesar 0,57; dan (3) produk tersebut efektif dalam meningkatkan motivasi belajar siswa, berdasarkan peningkatan rata-rata skor skala motivasi sebelum dan sesudah penggunaan produk sebesar 1,86\%.
\end{abstract}

Kata kunci: multimedia pembelajaran, game, RPG, lingkaran

\section{DEVELOPING A ROLE PLAYING GAME (RPG)-BASED INSTRUCTIONAL MULTIMEDIA ON THE SUBJECT OF CIRCLE FOR GRADE 8 STUDENTS OF JUNIOR HIGH SCHOOL}

\begin{abstract}
This research aimed to: (1) produce a RPG-based instructional multimedia on the subject of circle for grade 8students of junior high school feasible to use in learning processes, (2) identify the effectiveness of the developed product to promote conceptual understanding, and (3) identify the effectiveness of the developed product to promote learning motivation. This development study referred to the model suggested by Alessi \& Trollip. The developmental design was grouped into three steps, consisting of planning, design, and development. In all of the steps, on-going evaluation was done to monitor the quality of the developed product. The research findings revealed that: (1) the RPG-based instructional multimedia on the subject of circle for grade 8students of junior high school was feasible to use in learning processes based on the very good assessment given by subject matter experts and media experts, and very positive responses given by students; (2) the developed product was effective to promote conceptual understanding based on the gain score result of 0.57; and (3) the developed product was effective to promote learning motivation based on the increase of average score of motivation scale before and after the use of the product by $1.86 \%$.
\end{abstract}

Keywords: instructional multimedia, game, RPG, circle

Permalink/DOI: http://dx.doi.org/10.21831/jitp.v5i2.15048 


\section{Pendahuluan}

Pengetahuan atau keterampilan dapat dipelajari melalui lembaga pendidikan formal, non formal, dan informal. Sekolah merupakan lembaga pendidikan formal. Pembelajaran di sekolah dilaksanakan berdasarkan kurikulum tertentu sebagaimana diatur dalam Undang-undang No. 20 tahun 2003.

Kurikulum disusun sesuai jenjang pendidikan dalam kerangka Negara Kesatuan Republik Indonesia. Pada jenjang SMP/MTs, kurikulumnya memuat sepuluh mata pelajaran wajib, salah satunya adalah matematika. Matematika memuat aspek materi pelajaran konseptual dan praktis, sehingga siswa dituntut untuk tidak hanya memahami konsep, tetapi juga mengaplikasikan konsep tersebut. Aspek materi pelajaran yang wajib dipelajari oleh siswa SMP/MTs, yaitu bilangan, aljabar, geometri dan pengukuran, serta statistika dan peluang (Kementerian Pendidikan dan Kebudayaan, 2016, p. 3). Lingkaran merupakan salah satu materi pelajaran matematika tentang geometri dan pengukuran yang disampaikan di kelas VIII.

Penelitian yang dilakukan oleh Tun'isah (2011, p. viii) dan Rosyidi (2015, pp.131-132) menemukan bahwa siswa kelas VIII melakukan kesalahan dalam menyelesaikan soal dan mengalami kesulitan belajar matematikapada materi lingkaran. Kesalahan dan kesulitan tersebut juga dialami oleh siswa kelas VIII di MTs Negeri Kaliangkrik pada sub-materi sudut pusat dan sudut keliling. Menurut guru, siswa mengalami kesulitan ketika dihadapkan pada soal yang bervariasi sehingga terkadang melakukan kesalahan dalam mengidentifikasi sudut pusat dan sudut keliling. Kesulitan ini salah satunya disebabkan oleh kurangnya pemahaman siswa tentang konsep sudut pusat dan sudut keliling.

Masalah lain yang ditemukan di sekolah adalah ketidaktertiban siswa dalam mengerjakan PR. Pekerjaaan Rumah yang diberikan guru tidak selalu dikerjakan oleh siswa, bahkan ada sebagian siswa yang mencontek pekerjaan temannya. Ketidaktertiban siswa dalam mengerjakan PR merupakan salah satu tanda rendahnya motivasi siswa. Rendahnya motivasi siswa dapat mempengaruhi proses pembelajaran. Beberapa pengaruh motivasi terhadap pembelajaran yaitu mengarahkan perilaku ke tujuan, meningkatkan usaha dan sinergi, meningkatkan prakarsa (inisiasi) dan kegigihan terhadap berbagai aktivitas, mempengaruhi proses-proses kognitif, menentukan konsekuensi mana yang memberi penguatan dan hukuman, dan meningkatkan performa (Ormrod, 2009, pp. 58-59).

Motivasi siswa dapat meningkat dengan penggunaan media pembelajaran (Sanjaya, 2011, p. 209). Guru di sekolah tersebut sudah menggunakan media pembelajaran berupa slide presentasi sederhana, namun belum bias mengatasi masalah rendahnya motivasi belajar siswa. Salah satu alternatif solusi yang dapat dilakukan adalah dengan mengembangkan suatu media pembelajaran berupa game. Game cenderung disukai oleh anak-anak. Orang-orang yang bermain game menganggap game sebagai sarana hiburan yang menyenangkan dan menantang (Henry, 2010, p. 59).

RPG merupakan salah satu genre game favorit gamers Indonesia (Agate, 2012). RPG disukai oleh semua kalangan baik anak-anak, remaja, maupun orang dewasa (Baskoro, 2015). Pemain RPG bermain dengan memerankan sebuah karakter yang akan berkembang dan dapat berinteraksi dengan karakter lain (non-player character) mengikuti alur cerita yang telah ditentukan. Kelebihan RPG yaitu dapat memunculkan minat dan memotivasi siswa (Eustace, Mason, \& Swan, 2007, p. 254), dan memberikan beberapa kontribusi dalam kerja kelompok, seperti membangun kelompok yang efektif, memotivasi siswa yang lain, dan manajemen konflik (Baptisa, 2016, p. 32).

Multimedia pembelajaran berbasis RPG dapat menjadi salah satu alternatif solusi untuk mengatasi kurangnya pemahaman konsep dan motivasi belajar siswa. Multimedia pembelajaran adalah penggunaan beberapa format media sekaligus dalam 
sebuah tampilan yang integratif dan interaktif untuk menyajikan suatu informasi yang digunakan dalam rangkaian kegiatan yang dilakukan seseorang secara aktif untuk mencapai tujuan belajar tertentu. Penggunaan multimedia pembelajaran dapat memberikan beberapa manfaat, di antaranya yaitu meningkatkan hasil belajar (Jumasa \& Surjono, 2016; Nazalin \& Muhtadi, 2016), meningkatkan motivasi (Istiqlal \& Wutsqa, 2013), meningkatkan kemampuan berpikir kritis (Sari \& Sugiyarto, 2015), dan menstimulasi aspek kognitif dan bahasa (Widyatmojo \& Muhtadi, 2017).

Motivasi belajar siswa yang rendah dapat diatasi melalui penggunaan multimedia pembelajaran berbasis RPG. Caranya adalah dengan mengintegrasikan soal-soal latihan dalam multimedia tersebut sehingga siswa dapat belajar bermain. Soal-soal latihan tersebut dapat dijadikan bagian dari permainan yang harus dilalui siswa untuk menuju ke level berikutnya. Selain itu, sistem permainan dapat menerapkan pemberian penguatan positif dan negatif untuk memotivasi siswa. Penguatan positif dapat berupa pemberian hal-hal yang menguntungkan kondisi karakter pemain dalam permainan, seperti bintang, koin, nyawa, dan sebagainya. Sedangkan penguatan negatif yang diberikan dapat berupa pengurangan halhal menguntungkan yang telah dimiliki oleh karakter pemain.

Masalah kurangnya pemahaman konsep siswa juga dapat diatasi melalui penggunaan multimedia berbasis RPG, yaitu dengan menyajikan visualisasi konsep sudut pusat dan sudut keliling dalam video yang didesain dengan tepat. Video bermanfaat dalam membangun konsep, memahami isi materi, dan meningkatkan pengetahuan umum (Chen, Wei, \& Li, 2016, p. 162). Video didesain dengan berpedoman pada prinsip perancangan multimedia oleh (Mayer, 2009, pp. 267-268).

Multimedia pembelajaran berbasis RPG memadukan permainan dan pembelajaran melalui video untuk memvisualisasikan konsep, dan tantangan permainan berupa latihan soal. Sayangnya multimedia pembelajaran berbasis RPG masih jarang dijumpai. Oleh karena itu, penelitian ini akan berfokus pada pengembangan produk multimedia pembelajaran berbasis role-playing games (RPG) pada materi lingkaran untuk siswa SMP/MTs kelas VIII.

\section{Metode Penelitian}

Jenis penelitian ini adalah penelitian dan pengembangan atau disebut juga $R e-$ search and Development/R\&D. Produk yang dikembangkan dalam penelitian ini adalah multimedia pembelajaran berbasis roleplaying games (RPG). Produk ini berisi materi yang dispesifikasikan pada sub-materi lingkaran, yaitu sudut pusat dan sudut keliling untuk siswa SMP/MTs kelas VIII.

Model pengembangan yang digunakan dalam penelitian ini mengadaptasi model pengembangan multimedia pembelajaran yang dikembangkan oleh Alessi \& Trollip (2001, p. 410). Model tersebut terdiri dari tiga tahap utama, yaitu perencanaan (planning), perancangan (design), dan pengembangan (pengembangan).

Penelitian dan pengembangan ini dilaksanakan sejak Januari hingga Mei 2017. Pengambilan data untuk uji beta dan uji efektivitas dilaksanakan di MTs Negeri Kaliangkrik. Pengambilan data tersebut berlangsung dari 28 April sampai 17 Mei 2017.

Subjek uji coba dalam penelitian ini meliputi ahli materi, ahli media, dan siswa. Ahli media dan ahli materi berperan menilai kelayakan produk multimedia pembelajaran yang dihasilkan, dan siswa berperan sebagai sasaran pengguna produk (responden). Responden dalam penelitian ini adalah siswa kelas VIII MTs Negeri Kaliangkrik tahun ajaran 2016/2017 semester 2. Banyak subjek coba pada uji beta 1 adalah 12 orang siswa kelas VIII E yang mewakili kemampuan rendah, sedang dan tinggi. Sedangkan banyak subjek coba pada uji beta 2 adalah 40 orang siswa kelas VIII A.

Prosedur penelitian pengembangan ini terdiri dari dua aspek, yaitu pengembangan hingga dihasilkannya produk multimedia pembelajaran berbasis RPG yang 
layak, dan pengujian efektivitas produk tersebut. Uji efektivitas yang akan dilakukan pada penelitian ini meliputi uji efektivitas terhadap peningkatan pemahaman konsep dan motivasi belajar siswa.

Analisis kebutuhan dilakukan sebelum pengembangan produk dilakukan. Analisis kebutuhan dilakukan untuk menentukan materi yang akan dikembangkan dalam produk. Analisis kebutuhan dilakukan melalui kegiatan wawancara mengenai kesulitan belajar matematika terhadap guru dan siswa kelas VIII di MTs Negeri Kaliangkrik.

Prosedur penelitian ini terdiri dari tiga tahap utama, yaitu perencanaan, perancangan, dan pengembangan. Pelaksanaan ketiga tahap tersebut berpedoman pada kriteria produk multimedia pembelajaran berbasis RPG yang telah ditentukan. Selain itu, evaluasi berkelanjutan juga dilaksanakan pada keseluruhan tahap untuk memantau kualitas produk.

Tahap perencanaan terdiri dari mendefinisikan ruang lingkup kajian, mengidentifikasi karakteristik siswa, membuat dokumen perencanaan, menentukan dan mengumpulkan bahan, dan melakukan brainstorming. Selanjutnya tahap perancangan meliputi analisis konsep materi pembelajaran, menentukan komponen-komponen produk, membuat flowchart dan storyboard, dan menentukan software-software yang akan digunakan. Tahap terakhir yaitu tahap pengembangan, terdiri dari menyiapkan naskah, menyiapkan komponen-komponen multimedia, memproduksi multimedia pembelajaran berbasis RPG, melakukan ujian alfa, melakukan revisi 1 , melakukan uji beta 1 , melakukan revisi 2 , melakukan uji beta 2, melakukan revisi akhir, dan melakukan uji efektivitas.

Uji alfa dilakukan untuk menilai kelayakan produk yang dikembangkan. Penilaian dilakukan oleh dua ahli materi dan dua ahli media. Sedangkan uji beta dilakukan untuk mengetahui respon siswa terhadap produk yang dikembangkan. Uji beta dilaksanakan dua kali, yaitu pada kelompok terbatas dan pada kelompok besar.
Teknik pengumpulan data yang digunakan dalam penelitian ini yaitu wawancara, observasi, kuisioner (angket), dan tes. Wawancara dan observasi digunakan pada tahap pra-survei. Sedangkan angket dan tes digunakan pada tahap pengujian kelayakan dan efektifitas produk. Adapun instrumen yang digunakan untuk mengumpulkan datanya yaitu angket, skala, dan naskah tes.

Angket yang digunakan dalam penelitian ini berupa angket penilaian produk oleh ahli materi, angket penilaian produk oleh ahli media, dan angket respon. Angket tersebut dikembangkan dari kriteria penilaian multimedia pembelajaran berbasis RPG secara berturut-turut pada aspek desain instruksional, aspek desain tampilan dan navigasi, dan aspek sikap pengguna. Alternatif pilihan jawaban yang digunakan dalam angket tersebut ada empat dangan pertimbangan untuk menghindari jawaban pada kategori tiga yang cenderung dipilih (Mardapi, 2008, p. 121).

Skala yang digunakan berupa skala motivasi. Skala ini digunakan untuk mengumpulkan data motivasi belajar siswa sebelum dan sesudah menggunakan produk dalam pembelajaran. Alternatif jawaban yang digunakan dalam skala ini juga terdiri dari empat pilihan.

Tes digunakan dalam uji efektivitas penggunaan produk dalam meningkatkan pemahaman konsep siswa. Tes dilaksanakan dua kali, yaitu sebelum siswa belajar menggunakan produk (pre-test), dan sesudahnya (post-test). Perbandingan hasil kedua tes tersebut akan menentukan efektivitas produk dalam meningkatkan pemahaman konsep siswa. Naskah tes yang digunakan pada kedua tes tersebut paralel berupa 10 butir soal uraian.

Analisis data penelitian ini secara umum terdiri dari dua teknik, yaitu untuk data angket dan skala, dan data tes. Teknik analisis data angket dan skala berpedoman pada langkah-langkah yang dikemukakan oleh Sukardi (2013, p. 86), yaitu mendeskripsikan data, dan melakukan uji statistika. Adapun langkah dalam melakukan analisis 
data yang diperoleh dari angket penilaian produk baik oleh ahli materi dan ahli media yaitu pertama, mengubah data kualitatif yang diperoleh dari angket penilaian menjadi data kuantitatif, dengan ketentuan: sangat kurang $=1$, kurang $=2$, baik $=3$, dan sangat baik $=4$. Data kuantitatif yang terkumpul selanjutnya dihitung nilai rata-ratanya. Nilai rata-rata tersebut kemudian diubah menjadi nilai kualitatif sesuai dengan kriteria kategori (Mardapi, 2008, p. 123) penilaian ideal sesuai Tabel 1.

Tabel 1. Kriteria Kategori Penilaian Ideal

\begin{tabular}{cc}
\hline Interval & Kategori \\
\hline$\overline{\mathbf{X}}_{\mathbf{i}}+\mathbf{1 S B}_{\mathbf{i}} \leq \overline{\mathbf{X}}$ & Sangat Baik \\
$\overline{\mathbf{X}}_{\mathbf{i}} \leq \overline{\mathbf{X}}<\overline{\mathbf{X}}_{\mathbf{i}}+\mathbf{1} \mathbf{S B}_{\mathbf{i}}$ & Baik \\
$\overline{\mathbf{X}}_{\mathbf{i}}-\mathbf{1 S B}_{\mathbf{i}} \leq \overline{\mathbf{X}}<\overline{\mathbf{X}}_{\mathbf{i}}$ & Kurang \\
$\overline{\mathbf{X}}<\overline{\mathbf{X}}_{\mathbf{i}}-\mathbf{1 S B}_{\mathbf{i}}$ & Sangat Kurang \\
\hline
\end{tabular}

Produk dinyatakan layak jika mendapatkan penilaian minimal baik. Sedangkan analisis data angket respon siswa dan skala motivasi belajar juga menggunakan langkah yang sama, yang membedakan adalah ketentuan konversi data kualitatif menjadi kuatitatif, kriteria kategori respon ideal dan kriteria kategori motivasi ideal. Adapun ketentuan tersebut yaitu sangat tidak setuju $=1$, tidak setuju $=2$, setuju $=3$, dan sangat setuju $=4$. Inverval kriteria kategori respon ideal dan motivasi ideal sama dengan interval kriteria kategori penilaian ideal, yang berbeda adalah kategorinya. Kategori respon ideal terdiri dari sangat positif, positif, negatif, dan sangat negatif. Sedangkan kategori motivasi ideal terdiri dari sangat tinggi, tinggi, rendah, dan sangat rendah.

Analisis data tes dilakukan dengan menghitung nilai gain $(g)$. Nilai $g$ diperoleh dengan membandingkan rata-rata skor pretest dan post-test, dengan rumus (Hake, 1998, p. 65):

Keterangan:

$$
g=\frac{S_{f}-S_{i}}{100-S_{i}}
$$

$S_{f}:$ Rata-rata nilai post-test

$S_{i}$ : Rata-rata nilai pre-test
Nilai $g$ yang diperoleh selanjutnya diinterpretasikan sesuai dengan kriteria kategori nilai gain (Hake, 1998, p. 65) sesuai Tabel 2.

Tabel 2. Kriteria Kategori Nilai Gain

\begin{tabular}{cc}
\hline Interval & Kategori \\
\hline $\boldsymbol{g} \geq \mathbf{0 , 7}$ & Tinggi \\
$\mathbf{0 , 7}>\boldsymbol{g} \geq \mathbf{0 , 3}$ & Sedang \\
$\mathbf{0 , 3}>\boldsymbol{g}$ & Rendah \\
\hline
\end{tabular}

\section{Hasil Penelitian dan Pembahasan}

\section{Hasil Pengembangan}

Tahap perencanaan dimulai dengan mendefinisikan ruang lingkup kajian materi yang akan disajikan dalam produk. Ruang lingkup materi tersebut ditentukan dengan mempertimbangkan hasil penelitian yang dilakukan oleh Tun'isah (2011) dan Rosyidi (2015), dan hasil prasurvei serta wawancara dengan guru matematika dan siswa di MTs Negeri Kaliangkrik. Berdasarkan pertimbangan tersebut, ruang materi yang dipilih adalah sudut pusat dan sudut keliling.

Identifikasi karakteristik siswa dilakukan melalui wawancara dengan guru dan siswa, dan observasi di kelas. Hasil wawancara dan observasi tersebut menunjukkan bahwa siswa mengalami kesulitan dengan soal yang bervariasi. Kemudian dengan mempertimbangkan hasil belajar siswa sebelumnya, diperoleh informasi bahwa tingkat kemampuan siswa berbeda-beda. Tingkat kemampuan tersebut kemudian dikelompokkan menjadi tiga, yaitu, rendah, sedang, dan tinggi.

Dokumen perencanaan dibuat pada tahap ini, yaitu berupa dokumen kelengkapan mengajar, dokumen evaluasi, dan dokumen penilaian. Dokumen kelengkapan mengajar, seperti silabus, RPP, dan bahan ajar. Sumber-sumber referensi untuk bahan ajar kemudian ditentukan dan dikumpulkan dari http:/ / bse.kemdikbud.go.id berupa buku sekolah elektronik (BSE) matematika untuk kelas VIII yang dapat diunduh secara gratis. Sedangkan dokumen evaluasi dan penilaian ditentukan kisi-kisinya pada 
tahap ini. Langkah selanjutnya adalah melakukan brainstorming dengan berdiskusi dengan guru matematika di sekolah dan teman sejawat. Diskusi dengan guru bertujuan untuk mematangkan aspek materi. Sedangkan diskusi dengan teman sejawat bertujuan untuk mendapatkan masukan dan saran dari aspek pengembangan.

Tahap berikutnya adalah tahap perancangan. Langkah pertama yang dilakukan adalah analisis konsep materi pembelajaran. Pada langkah ini, bahan ajar yang telah dikumpulkan disesuaikan cakupan pembahasan dan urutannya dengan tujuan pembelajaran yang telah ditentukan. Selanjutnya komponen-komponen multimedia pembelajaran berbasis ditentukan. Komponen tersebut terdiri dari komponen RPG, seperti narasi, grafis, plugin, dan audio, dan komponen pembelajaran, seperti video, butir-butir soal latihan dengan tiga tingkat kesukaran, dan pembahasannya. Pada tahap ini juga dihasilkan flowchart dan storyboard.

Naskah narasi yang akan ditampilkan sebagai alur permainan dalam multimedia pembelajaran berbasis RPG disiapkan pada tahap pengembangan. Selanjutnya komponen-komponen produk yang terdiri dari komponen RPG dan komponen pembelajaran disiapkan. Beberapa komponen gambar untuk RPG diedit dari database RPG Maker MV dan beberapa sumber lain sesuai dengan kebutuhan narasi. Proses pengeditan dilakukan dengan menggunakan program Adobe Photoshop CS6. Komponen lain seperti animasi, audio, dan script plugin tidak memerlukan pengeditan sehingga siap untuk digunakan.

Komponen pembelajaran yang terdiri dari teks, grafis, dan audio dipadukan menjadi video. Komponen grafis dihasilkan menggunakan program GeoGebra agar dihasilkan bentuk visual yang akurat. Grafis tersebut kemudian dipadukan dengan teks menggunakan program Microsoft Office: PowerPoint 2013 untuk menghasilkan slide video. Video tersebut dirancang dengan berpedoman pada prinsip-prinsip rancangan multimedia (Mayer, 2009, pp. 267-268).
Video materi pembelajaran disajikan dalam teks dan grafis sesuai prinsip multimedia. Teks dan grafis yang dimasukkan dalam video merupakan teks dan grafis yang menjelaskan materi sudut pusat dan sudut keliling, seperti grafis ilustrasi sudut. Sedang teks atau grafis lain yang tidak berhubungan dengan materi tersebut tidak dimasukkan dalam video. Hal ini dilakukan sesuai dengan prinsip koherensi. Selanjutnya, sesuai dengan prinsip memberikan sinyal, bagian objek dalam grafis dan teks keterangannya diberikan warna yang sama agar memudahkan siswa dalam mengenali bagian yang dimaksud. Teks dan grafis tersebut juga disajikan berdekatan satu sama lain dalam layar secara bersamaan sesuai dengan prinsip hubungan rungan dan waktu.

Materi sudut pusat dan sudut keliling disajikan dalam lima video: (1) tentang konsep sudut pusat dan sudut keliling, (2) tentang hubungan sudut pusat dan sudut keliling, (3) sifat sudut keliling yang menghadap diameter lingkaran, (4) sifat sudut keliling yang menghadap busur yang sama, dan (5) hubungan besar sudut pusat, panjang busur, dan luas juring lingkaran. Pembagian materi dalam lima video sesuai dengan prinsip pembagian. Pada video pertama, sebelum siswa dikenalkan dengan konsep sudut pusat dan sudut keliling, siswa terlebih dahulu diingatkan kembali dengan bagian-bagian sudut. Hal ini dilakukan sesuai dengan prinsip pra-pelatihan, dan juga sebagai bantuan untuk siswa mengingat kembali materi yang telah dipelajari sebelumnya sehingga siswa dapat memahami konsep sudut pusat dan sudut keliling dengan lebih mudah.

Video tersebut kemudian dipadukan dengan musik efek, dan disesuaikan timing-nya menggunakan program Camtasia Studio 8. Selanjutnya, video yang dihasilkan dari program tersebut tersebut dikonversi ke format .webm menggunakan program BENCOS. Format tersebut diperlukan dalam produk yang akan dihasilkan menggunakan RPG Maker MV untuk komputer dengan sistem operasi Windows. 
Komponen RPG dan komponen pembelajaran yang telah siap kemudian digabung menggunakan program RPG Maker $M V$ sesuai dengan naskah narasi dalam file ".rpgproject". Langkah akhir untuk menghasilkan produk multimedia pembelajaran berbasis RPG adalah dengan mendeployfile .rpgproject menjadi sebuah program berekstensi .exe yang siap dijalankan pada komputer dengan sistem operasi Windows.

Produk multimedia pembelajaran berbasis RPG yang dihasilkan diberi judul "Petualangan 8 Guci" dengan tampilan halaman depan dapat dilihat pada gambar 1 . Produk tersebut terdiri dari tiga bagian cerita, yaitu bagian pembuka, bagian inti, dan bagian penutup. Bagian pembuka berisi penyajian tujuan pembelajaran, scene intro, dan scene prolog. Scene intro merupakan bagian di mana pemain memilih karakter pemainnya dan menginputkan nama karakter yang dipilih. Scene selanjutnya adalah scene prolog di mana pada bagian ini disajikan kilas balik dari cerita yang akan disajikan dan awal misteri yang akan dipecahkan oleh pemain.

Bagian inti terdiri dari empat bagian yang dibedakan berdasarkan area latar cerita tersebut. Keempat area tersebut mewakiliki empat sub-materi sudut pusat dan sudut keliling yang disajikan, yaitu (1) konsep dasar sudut pusat dan sudut keliling, (2) hubungan sudut pusat dan sudut keliling, (3) sifat-sifat sudut keliling, dan (4) hubungan sudut pusat, panjang busur, dan luas juring. Pada tiap area siswa akan mempelajari satu sub-materi melalui video pembelajaran, dan menghadapi tantangan permainan yang berupa latihan soal. Pada tiap area siswa dapat menyimpan progress permainannya melalui menu penyimpanan sehingga siswa dapat berhenti bermain tanpa harus khawatir kehilangan progress yang telah dicapainya, dan dapat bermain kembali sesuai data penyimpanan terakhir. Menu penyimpanan tersebut dapat diakses melalui "kristal menu" dalam permainan dengan tampilan seperti yang tampak pada Gambar 2.

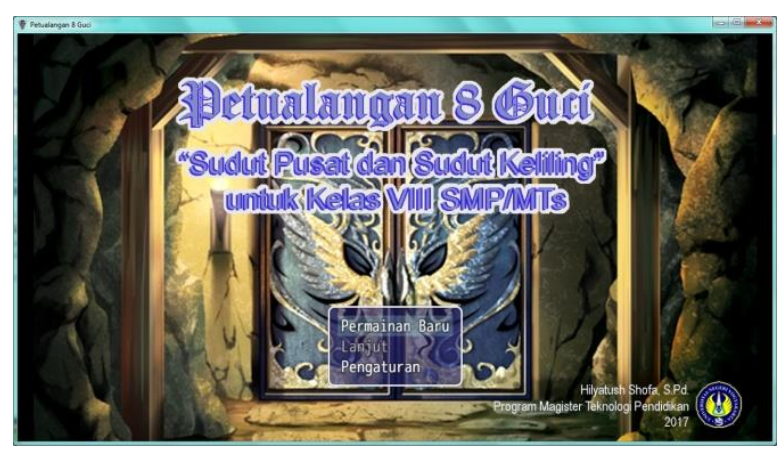

Gambar 1. Tampilan Title Screen

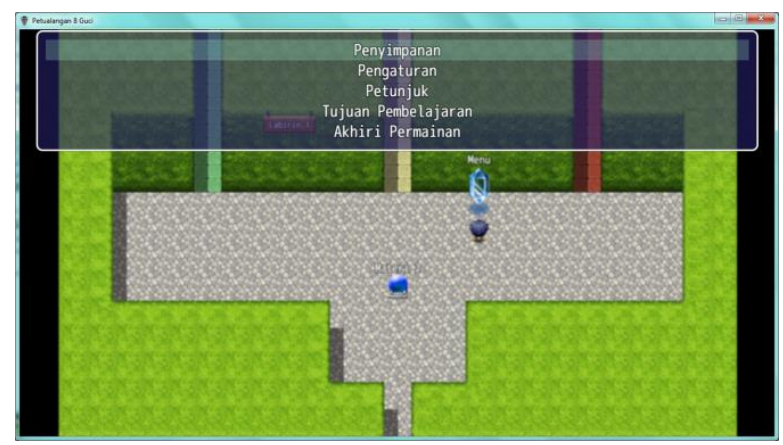

Gambar 2. Tampilan Isi Menu

Siswa memiliki tiga pilihan tingkat kesulitan soal yaitu mudah, sedang, dan sulit yang masing-masing diwakili oleh warna hijau, kuning, dan merah secara berturutturut. Setiap siswa mengerjakan soal dengan benar, karakter yang dimainkan siswa akan mendapatkan koin sesuai tingkat kesulitan soal, yaitu perunggu untuk soal mudah, perak untuk soal sedang, dan emas untuk soal sulit. Setiap 5 koin perunggu atau 4 koin perak atau 3 koin emas secara otomatis akan memberikan tambahan satu kesempatan kepada karakter pemain. Namun, jika siswa menjawab salah, karakter pemainnya akan kehilangan satu kesempatan dan kemudian karakter pemain akan dialihkan ke tempat sebelumnya untuk memilih untuk mengerjakan soal yang sama atau berbeda. Permainan berakhir jika kesempatan yang dimiliki karakter pemain habis atau nol. Pada awal permainan, karakter pemain memiliki tiga kesempatan.

Jumlah butir soal yang harus dijawab oleh siswa pada area pertama ada 5 butir, dan pada setiap tiga area selanjutnya ada 4 butir. Pada bagian akhir setiap area terdapat tahap bonus. Tahap bonus tersebut 
berupa tantangan yang mengharuskan siswa untuk menyusun tiga objek batu membentuk sudut pusat atau sudut keliling sesuai petunjuk yang diberikan. Tiga objek batu tersebut mewakili titik-titik sudut, dan sudut yang harus dibentuk berbeda-beda disetiap area sesuai dengan gambar yang disediakan. Reward yang diberikan pada tahap bonus adalah pemain dapat memilih salah satu koin dari koin perunggu, koin perak dan koin emas yang muncul.

Bagian akhir berisi scene epilog cerita dan pembahasan soal. Setelah scene epilog disajikan, siswa dapat mengendalikan karakter pemainnya untuk mengakses pembahasan soal yang disediakan. Pembahasan soal yang dapat diakses hanya pembahasan dari soal-soal yang pernah dicoba oleh siswa sebelumnya. Produk tersebut selanjutnya diuji kelayakan dan efektivitasnya.

\section{Hasil Uji Alfa}

Ahli materi menilai produk multimedia pembelajaran berbasi RPG berdasarkan dua aspek, yaitu aspek pembelajaran dan aspek materi. Penilaian ahli materi pada aspek pembelajaran didasarkan pada lima indikator penilaian. Rata-rata skor penilaian yang diberikan ahli materi adalah 3,40. Rata-rata jumlah skor tersebut termasuk pada kategori sangat baik dengan persentase $85,00 \%$. Sedangkan penilaian pada aspek materi didasarkan pada sepuluh indikator. Rata-rata skor penilaian yang diberikan oleh ahli materi adalah 3,36. Rata-rata skor tersebut termasuk kategori sangat baik dengan persentase $84,09 \%$. Adapun rata-rata skor keseluruhan yang diperoleh adalah 3,38 dengan persentase $84,38 \%$. Rata-rata skor tersebut termasuk pada kategori sangat baik. Adapun data penilaian produk oleh ahli materi secara visual terlihat pada gambar 3 .

Ahli media menilai produk multimedia pembelajaran berbasis RPG berdasarkan dua aspek, yaitu aspek tampilan dan aspek navigasi. Aspek tampilan dinilai berdasarkan 12 indikator penilaian. Rata-rata skor penilaian yang diberikan ahli media adalah 3,30. Rata-rata jumlah skor tersebut termasuk pada kategori sangat baik dengan persentase $82,50 \%$. Sedangkan penilaian pada aspek navigasi didasarkan pada tujuh indikator. Rata-rata skor penilaian yang diberikan oleh ahli media adalah 3,00. Ratarata skor tersebut termasuk kategori sangat baik dengan persentase $75,00 \%$. Adapun rata-rata skor keseluruhan yang diperoleh adalah 3,20 dengan persentase 80,11\%. Rata-rata skor tersebut termasuk pada kategori sangat baik. Adapun data penilaian produk oleh ahli media secara visual terlihat pada gambar 4 .

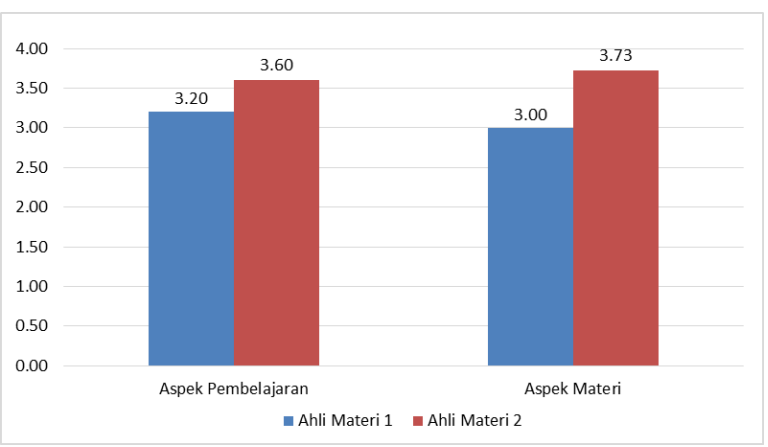

Gambar 3. Chart Rata-rata Skor Penilaian Ahli Materi

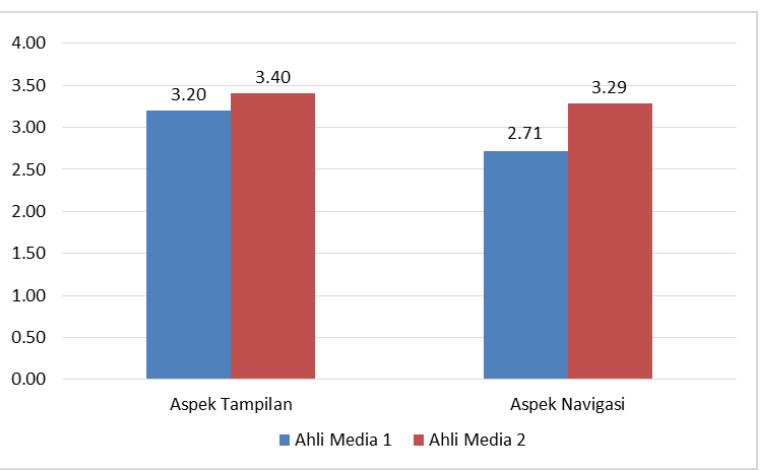

Gambar 4. Chart Rata-rata Skor Penilaian Ahli Media

\section{Hasil Uji Beta}

Produk multimedia pembelajaran berbasis RPG telah memenuhi penilaian minimal baik dari ahli materi dan ahli media sehingga dinyatakan layak Untuk digunakan dalam pembelajaran. Selanjutnya produk tersebut diuji penggunaannya oleh siswa dalam uji beta. Uji beta dilakukan dalam dua tahap, yaitu uji beta 1 dan uji 
beta 2 . Uji beta 1 dilakukan pada 12 siswa dari kelas VIII E dengan tujuan untuk mengetahui respon siswa terhadap produk yang dihasilkan sebelum digunakan dalam proses pembelajaran di kelas. Uji beta 1 dilaksanakan dalam satu pertemuan dengan waktu sekitar 2 jam. Di akhir uji coba, setiap siswa mengisi angket respon yang telah disediakan. Respon yang diberikan mencakup empat aspek, yaitu kemudahan, kebermanfaatan, daya tarik, dan motivasi. Ratarata skor keseluruhan data respon tersebut adalah 3,42 dengan persentase $85,53 \%$. Rata-rata skor tersebut berada pada kategori sangat positif. Hal tersebut menunjukkan bahwa siswa memberikan respon yang sangat positif terhadap penggunaan produk multimedia pembelajaran berbasis RPG sehingga produk yang dikembangkan dapat digunakan dalam proses pembelajaran. Adapun rata-rata skor respon siswa pada uji beta 1 secara visual dapat dilihat pada gambar 5 .

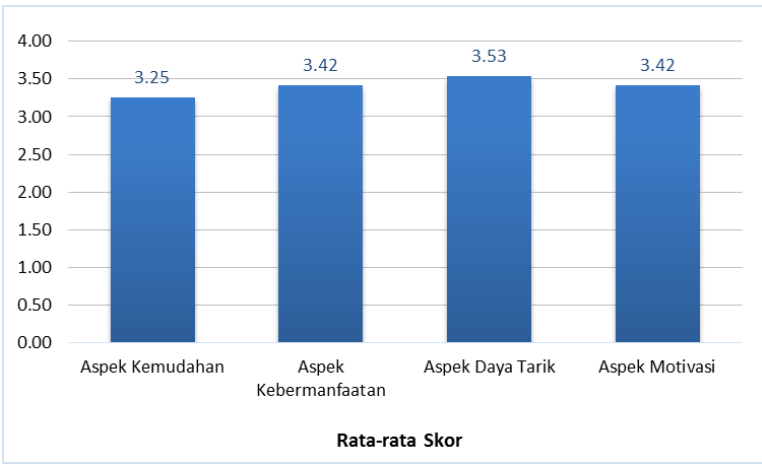

Gambar 5. Chart Rata-rata Skor Respon Siswa pada Uji Beta 1

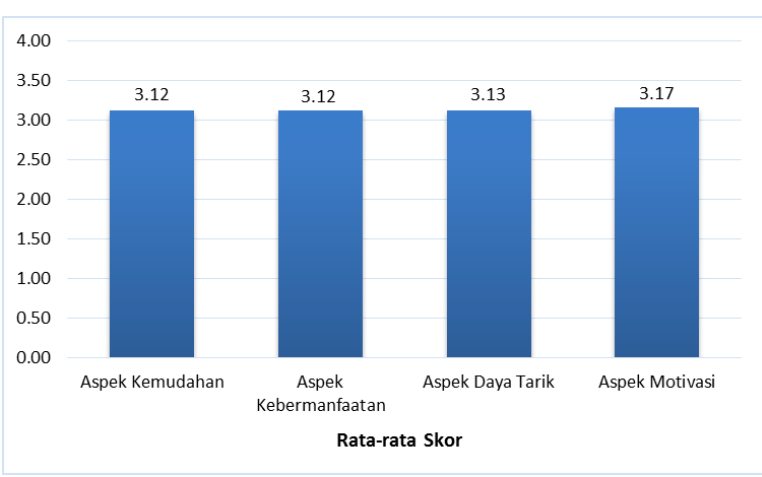

Gambar 6. Chart Rata-rata Skor Respon Siswa pada Uji Beta 2
Uji beta 2 dilakukan kepada siswa kelas VIII A yang berjumlah 40 orang. Pengujian ini dilaksanakan dalam tiga pertemuan. Pada tiap pertemuan siswa mempelajari minimal satu subbab materi dengan menggunakan produk multimedia pembelajaran berbasis RPG. Kemudian pada pertemuan akhir, siswa mengisi angket respon untuk memberikan penilaian terhadap produk multimedia pembelajaran berbasis RPG yang digunakan. Pengisian angket respon untuk uji beta 2 dilaksanakan pada tanggal 16 Mei 2017 dengan melibatkan 38 siswa. Angket respon yang digunakan merupakan angket yang sama dengan angket yang digunakan pada uji beta 1 , sehingga terdapat empat aspek respon yang dinilai. Ratarata keseluruhan skor data respon siswa pada uji beta 2 adalah 3,14 dengan persentase $78,60 \%$. Rata-rata skor tersebut termasuk kategori sangat positif. Hal ini menunjukkan bawa siswa merasa tertarik untuk menggunakan produk yang dikembangkan dalam pembelajaran. Adapun rata-rata skor respon siswa pada uji beta 2 secara visual dapat dilihat pada gambar 6 .

\section{Hasil Pre-test dan Post-test}

Data pre-test dan post-test digunakan untuk menentukan efektivitas produk multimedia pembelajaran berbasis RPG dalam meningkatkan pemahaman konsep siswa. Pre-test dilaksanakan sebelum siswa kelas VIII A menggunakan produk multimedia pembelajaran berbasis RPG dalam proses pembelajaran. Pre-test dilaksanakan pada tanggal 25 April 2017 dan melibatkan 38 siswa karena 2 siswa lain tidak hadir.

Post-test dilaksanakan setelah siswa menggunakan produk multimedia pembelajaran berbasis RPG dalam proses pembelajaran selama tiga pertemuan. Post-test dilaksanakan pada tanggal 17 Mei 2017. Post-test dilakukan kepada 37 siswa karena 2 siswa mengikuti kegiatan pelatihan pramuka dan seorang siswa lain tidak hadir. Jumlah dan rata-rata skor pre-test dan post-test dari 35 orang siswa dapat dilihat pada Tabel 3. 
Tabel 3. Hasil Pre-Test dan Post-Test

\begin{tabular}{ccc}
\hline \multirow{2}{*}{ Kategori } & \multicolumn{2}{c}{ Skor } \\
& Pre-test & Post-test \\
\hline Jumlah & 1107 & 2468 \\
Rata-rata & 31,63 & 70,51 \\
\hline
\end{tabular}

Tabel 3 menunjukkan bahwa ratarata skor pre-test $\left(S_{i}\right)$ adalah 31,63dan ratarata skor post-test $\left(S_{f}\right)$ adalah 70,51 . Berdasarkan data tersebut, maka nilai gain $(g)$ yang diperoleh adalah 0,57 . Nilai gain tersebut berada pada kategori sedang sesuai dengan tabel2. Peningkatan nilai postest terhadap nilai pre-test menunjukkan bahwa secara umum pemahaman konsep siswa meningkat pada kategori sedang setelah mereka belajar menggunakan produk yang dikembangkan dalam proses pembelajaran. Sedangkan persentase ketuntasan belajar dengan kriteria ketuntasan minimal (KKM) 70 dicapai oleh 22 siswa dari 35 orang.

\section{Hasil Skala Motivasi}

Data skala motivasi digunakan untuk menentukan efektivitas produk multimedia pembelajaran berbasis RPG dalam meningkatkan motivasi belajar siswa. Skala motivasi disebarkan kepada siswa sebelum dan sesudah mereka menggunakan produk. Hal ini dilakukan untuk melihat perbedaan data skala motivasi sebelum dan sesudah siswa menggunakan produk dalam proses pembelajaran.

Skala motivasi disebarkan kepada siswa bersamaan dengan pre-test dan posttest, yaitu pada tanggal 25 April 2017 dan 17 Mei 2017. Aspek motivasi yang dilihat meliputi keuletan, ketekunan, persistensi terhadap tujuan, minat, dan kualifikasi prestasi. Adapun data skala motivasi sebelum dan sesudah penggunaan produk multimedia intruksional berbasis RPGyang melibatkan 35 siswa dapat dilihat pada Tabel 4.

Meskipun rata-rata jumlah skor motivasi belajar siswa sebelum dan setelah menggunakan produk multimedia pembelajaran berbasis RPG sama-sama berada pada kategori tinggi, namun terlihat bahwa terdapat selisih antara rata-rata motivasi belajar sebelum dan sesudah menggunakan produk tersebut. Selisih tersebut menunjukkan adanya peningkatan rata-rata skor motivasi yang besarnya adalah 1,49 atau 1,86\%. Peningkatan tersebut meliputi peningkatan pada kelima aspek motivasi belajar.

Tabel 4. Hasil Skala Motivasi Belajar

\begin{tabular}{|c|c|c|c|}
\hline \multirow[b]{2}{*}{ Aspek } & \multicolumn{2}{|c|}{ Rata-rata Skor } & \multirow[b]{2}{*}{$\begin{array}{c}\text { Ketera } \\
\text { ngan }\end{array}$} \\
\hline & $\begin{array}{l}\text { Sebe- } \\
\text { lum }\end{array}$ & $\begin{array}{l}\text { Sesu- } \\
\text { dah }\end{array}$ & \\
\hline a. Keuletan & 14,69 & 14,89 & Tinggi \\
\hline b. Ketekunan & 14,74 & 14,94 & Tinggi \\
\hline $\begin{array}{l}\text { c. Persistensi } \\
\text { terhadap tujuan }\end{array}$ & 2,86 & 2,91 & Tinggi \\
\hline d. Minat & 16,20 & 17,03 & $\begin{array}{l}\text { Sangat } \\
\text { Tinggi }\end{array}$ \\
\hline $\begin{array}{l}\text { e. Kualifikasi } \\
\text { prestasi }\end{array}$ & 9,46 & 9,66 & Tinggi \\
\hline $\begin{array}{l}\text { Rata-rata } \\
\text { Keseluruhan }\end{array}$ & 57,94 & 59,43 & \\
\hline Keterangan & Tinggi & Tinggi & \\
\hline Persentase & $\begin{array}{c}72,43 \\
\%\end{array}$ & $\begin{array}{c}74,29 \\
\%\end{array}$ & \\
\hline
\end{tabular}

Frekuensi dan persentase banyaknya siswa pada setiap kategori selanjutnya dihitung. Distribusi frekuensi dan persentase motivasi belajar 35 siswa sebelum dan sesudah menggunakan multimedia pembelajaran berbasis RPG dapat dilihat pada Tabel 5.

Tabel 5. Distribusi Frekuensi dan Persentase Motivasi Belajar

\begin{tabular}{ccccc}
\hline \multirow{2}{*}{ Kategori } & \multicolumn{2}{c}{ Sebelum } & \multicolumn{2}{c}{ Sesudah } \\
& $F$ & $\%$ & $F$ & $\%$ \\
\hline Sangat Tinggi & 16 & 45.71 & 16 & 45.71 \\
Tinggi & 17 & 48.57 & 18 & 51.43 \\
Rendah & 1 & 2.86 & 1 & 2.86 \\
Sangat Rendah & 1 & 2.86 & 0 & 0.00 \\
\hline
\end{tabular}

Data pada Tabel 5 menunjukkan bahwa sebelum produk multimedia pembelajaran berbasis RPG digunakan dalam pembelajaran, motivasi belajar 35 siswa di kelas VIII A menyebar pada semua kategori. Sedangkan setelah siswa belajar menggunakan produk multimedia intruksional berbasis RPG, penyebaran motivasi belajar hanya 
meliputi tiga kategori, yaitu rendah, tinggi, dan sangat tinggi. Pada kategori rendah dan sangat tinggi, frekuensinya tetap. Sedangkan pada kategori tinggi terdapat peningkatan 1 siswa.

\section{Pembahasan}

Produk multimedia pembelajaran berbasis RPG pada materi lingkaran dikembangkan dengan menggunakan program RPG Maker MV dan program-program pendukung lainnya. Produk ini merupakan salah satu sumber belajar pelengkap yang bertujuan untuk memudahkan siswa dalam memahami konsep sudut pusat dan sudut keliling, dan memotivasi siswa dalam mengerjakan latihan soal, khususnya PR. Video pembelajaran yang disajikan dalam produk tersebut dikembangkan dengan berpedoman pada 7 dari 12 prinsip perancangan multimedia Mayer (2009, pp. 267268), yaitu prinsip koherensi (coherence principle), prinsip pemberian tanda (signalling principle), prinsip hubungan ruang (spatial contiguity principle), prinsip hubungan waktu (temporal contiguity principle), prinsip pembagian (segmenting principle), prinsip pra-pelatihan (pre-training principle), dan prinsip multimedia (multimedia principle). Bentuk penerapan prinsip koherensi pada produk yang dikembangkan adalah dengan penggunaan teks dan grafis yang berhubungan dan mendukung materi yang disajikan saja. Penerapan prinsip pemberian tanda adalah dengan menampilkan grafis dan teks keterangannya dengan warna yang sama. Hal ini bertujuan agar memudahkan siswa dalam mengenali bagian yang dimaksud. Bentuk penerapan prinsip hubungan ruang dan waktu adalah dengan menyajikan teks dan grafis berdekatan satu sama lain dalam layar secara bersamaan. Prinsip pembagian diterapkan dengan penyajian materi dalam lima video yang terpisah. Bentuk penerapan prinsip pra-pelatihan adalah dengan penyajian konsep bagian-bagian sudut sebelum penyajian konsep sudut pusat dan sudut keliling. Hal ini bertujuan agar siswa dapat mengingat kembali bagi- an-bagian sudut sehingga siswa dapat memahami konsep sudut pusat dan sudut keliling dengan lebih mudah. Terakhir, prinsip multimedia diterapkan melalui penggunaan grafis dan teks dalam penyajian materi pembelajaran daripada teks saja.

Pengembangan multimedia pembelajaran berbasis RPG berdasarkan teori belajar behaviouristic, konstruktivistik, dan kognitivistik. Menurut teori behaviouristik, tingkah laku dapat berubah sesuai dengan stimulus yang diberikan, begitu pula dengan hasil belajar. Tingkah laku seseorang dapat dipengaruhi melalui pemberian penguatan positif dan penguatan negatif sesuai dengan teori hukum akibat (law of effect). Penerapan teori ini dalam produk adalah dengan menyediakan tantangan baik berupa latihan soal atau tantangan dengan pilihan jawaban yang terbatas. Umpan balik yang diberikan atas respon tantangan tersebut berupa pesan "benar" atau "salah", dan diikuti oleh pesan yang memberikan penguatan. Umpan balik positif meningkatkan dan menjaga motivasi dalam jangka panjang, sedangkan umpan balik negatif dapat memperbaiki performa jangka pendek (Burgers, Eden, van Engelenburg, \& Buningh, 2015). Selain itu, apabila jawaban benar, siswa akan mendapatkan suatu hadiah berupa bintang, nyawa, poin, atau hal lain yang menguntungkan kondisi karakternya dalam permainan sebagai bentuk penguatan positif. Sedangkan bila jawaban siswa salah, siswa akan mendapatkan suatu hukumanberupa pengurangan hal-hal yang menguntungkan karakternya dalam permainan.

Penganut teori konstruktivistik meyakini bahwa pengetahuan dibangun dalam diri seseorang bukan diatur dari luar. Proses belajar menurut Piaget terdiri dari tiga tahapan, yaitu asimilasi, akomodasi, dan ekuilibrasi (Siregar \& Nara, 2014, p. 30). Pada tahap akomodasi, pembelajar akan membangun kembali struktur pengetahuannya terhadap pengetahuan baru yang diterimanya. Penerapan teori ini dalam produk adalah dengan menyediakan video yang menyajikan konsep bagian-bagian 
sudut sebelum siswa belajar konsep sudut pusat dan sudut kelililing. Hal ini dapat memudahkan siswa dalam menghubungkan konsep sudut pusat dan sudut keliling dengan konsep sudut yang telah dipelajarinya.

Teori kognitivistik menekankan proses belajar dari pada hasil. Pengetahuan dibentuk melalui pemrosesan informasi dalam memori siswa. Agar informasi tersebut dapat diproses dan disimpan dalam memori jangka panjang siswa, maka diperlukan struktur pembelajaran yang tepat. Oleh karena itu, multimedia pembelajaran berbasis RPG dirancang sesuai dengan events of instruction dari Gagne, Briggs, \& Wager (1992) yang terdiri dari (1) mendapatkan perhatian peserta didik, (2) menginformasikan peserta didik tujuan pembelajaran, (3) merangsang mengingat pelajaran/pengetahuan sebelumnya, (4) menyajikan isi, (5) memberikan bimbingan belajar, (6) menghasilkan kinerja (praktek), (7) memberikan umpan balik, (8) menilai kinerja, dan (9) meningkatkan penguatan (retensi) dan alih pengetahuan (transfer).

Produk multimedia pembelajaran berbasis RPG yang dihasilkan kemudian diuji alfa oleh dua ahli materi dan dua ahli media, diuji beta oleh siswa kelas VIII MTs Negeri Kaliangkrik, dan diuji efektivitasnya dalam meningkatkan pemahaman konsep dan motivasi belajar. Hasil pengujian alfa menunjukkan bahwa produk yang dikembangkan layak digunakan dalam pembelajaran berdasarkan penilaian sangat baik yang diberikan oleh ahli materi dan ahli media. Hasil pengujian beta menunjukkan respon sangat positif yang diberikan oleh siswa. Hasil uji efektivitas menunjukkan bahwa produk yang dikembangkan dapat meningkatkan pemahaman konsep dan motivasi belajar siswa.

Keunggulan produk multimedia pembelajaran berbasis RPG yang dikembangkan, adalah tersedianya soal yang bervariasi. Soal yang bervariasi memungkinkan siswa untuk belajar sesuai dengan kemampuannya. Soal yang bervariasi juga dapat memberikan kesempatan kepada siswa untuk melatih kemampuannya dengan mengerjakan soal dengan tingkat kesulitan yang berbeda-beda.

Produk multimedia pembelajaran berbasis RPG yang dikembangkan memiliki beberapa kelemahan. Kelemahan yang pertama yaitu tidak ada tombol navigasi, seperti play, pause, forward, rewind, dan stop, ketika memutar video. Kelemahan lain yaitu video materi dan soal-soal yang terdapat dalam produk tidak dapat diperbaharui sendiri oleh guru.

\section{Simpulan}

Produk multimedia pembelajaran berbasis RPG dihasilkan melalui tiga tahap penelitian pengembangan, yaitu perencanaan, perancangan, dan pengembangan. Tahap perencanaan meliputi penentuan ruang lingkup kajian, identifikasi karakter siswa, pembuatan dokumen perencanan, penentuan dan pengumpulan bahan, serta brainstorming. Tahap perancangan meliputi analisis konsep materi, penentuan komponenkomponen produk, pembuatan flowchart dan storyboard, serta penentuan software yang akan digunakan. Terakhir tahap pengembangan meliputi persiapan naskah dan komponen-komponen multimedia, dan dilanjutkan dengan proses produksi dan pengujian produk. Berdasarkan hasil pengujian, produk yang dikembangkan dinyatakan layak digunakan dalam proses pembelajaran ditinjau dari materi dan media serta respon siswa. Kelayakan tersebut dapat dilihat dari rata-rata skor penilaian ahli materi sebesar 3,38 termasuk kategori sangat baik, dan ahli media 3,20 termasuk kategori sangat baik. Sedangkan rata-rata skor respon siswa pada uji beta 1 dan uji beta 2 berturut-turut adalah 3,42 dan 3,14, keduanya termasuk kategori sangat positif.

Produk multimedia pembelajaran berbasis RPG dinilai efektif dalam meningkatkan pemahaman konsep siswa yang ditunjukkan dengan nilai gain 0,57. Nilai tersebut menunjukkan bahwa produk yang dikembangkan dapat meningkatkan pemahaman konsep pada kategori sedang. Pro- 
duk multimedia pembelajaran berbasis RPG dinilai efektif dalam meningkatkan motivasi belajar siswa yang ditunjukkan dengan peningkatan rata-rata skor skala motivasi belajar siswa sebelum dan sesudah menggunakan produk yang dikembangkan dalam proses pembelajaran sebesar 1,86\%.

Pemanfaatan produk multimedia pembelajaran berbasis RPG pada materi lingkaran untuk siswa SMP/MTs kelas VIII sebagai pelengkap tercapainya tujuan belajar sebaiknya dapat memperhatikan cara penyampaian yang tepat. Guru diharapkan dapat menjelaskan dan mendemonstrasikan cara pengoperasian produk terlebih dahulu agar siswa lebih mudah dan nyaman dalam menggunakan produk. Selain itu, guru juga perlu mengingatkan kembali materi yang mendukung materi sudut pusat dan sudut keliling yang telah dipelajari siswa sebelumnya, seperti materi bagian-bagian sudut, agar siswa lebih mudah dalam menghubungkan materi sudut pusat dan sudut keliling yang akan dipelajarinya.

Agar guru dapat memantau perkembangan belajar siswa, guru dapat meminta siswa untuk menyiapkan buku tugas atau mencetak worksheet yang berguna sebagai sarana bagi siswa untuk menuliskan rangkuman materi dan uraian jawaban soal yang diperoleh selama siswa belajar menggunakan produk. Bila guru dan siswa sudah terbiasa menggunakan internet, guru dapat membuat forum diskusi online di mana siswa bisa mengunggah hasil kemajuannya bermain sebagai alternatif sarana bagi guru untuk memantau perkembangan belajar siswa.

\section{Daftar Pustaka}

Agate. (2012). Hasil survey gamer Indonesia. Retrieved August 10, 2016, from http://blog.agatestudio.com/2012/02 / hasil-survey-gamer-indonesiafebruari-2012/

Alessi, S. M., \& Trollip, S. P. (2001). Multimedia for learning: methods and development (3rd ed.). Boston: Allyn and Bacon.

Baptisa, R. (2016). Relation between game genres and competences for in-game certification. SGAMES 2015, LNICST

161. (A. Coelho \& C. V. de Carvalho, Eds.).

Baskoro, R. (2015). Game online Indonesia tahun 2014: Ikhtisar dan infografis. Retrieved August 10, 2016, from http://www.duniaku.net/2015/02/2 0/game-online-indonesia-tahun-2014ikhtisar-dan-infografis/

Burgers, C., Eden, A., van Engelenburg, M. D., \& Buningh, S. (2015). How feedback boots motivation and play in a brain-training game. Computers in Human Behavior, 48, 94-103.

Chen, B., Wei, L., \& Li, H. (2016). Teaching complicated conceptual knowledge with simulation videos in foundational electrical engineering cources. Journal of Technology and Science Education (JOTSE, 6, 145-147.

Eustace, K., Mason, C., \& Swan, M. (2007). Scupper's Island: Using game design and role play to learn about professional ethics. In Proceedings ASCILITE 2007: ICT: Providing Choices for Learners and Learning (pp. 251-255).

Gagne, R. M., Briggs, L. J., \& Wager, W. W. (1992). Principle of instructional design (4th ed.). Fort Worth, TX: Harcourt Brace Jovanovich.

Hake, R. R. (1998). Interactive-engagement versus traditional methods: A sixthousand-student survey of mechanics test data for introductory physics courses. American Journal of Physics, 66(1), 64-74. https:// doi.org/10.1119/1.18809

Henry, S. (2010). Cerdas dengan game: Panduan praktis bagi orangtua dalam mendampingi anak bermain game. Jakarta: Gramedia Pustaka Utama.

Istiqlal, M., \& Wutsqa, D. U. (2013). Pengembangan multimedia 
pembelajaran matematika SMA untuk meningkatkan motivasi dan prestasi belajar Matematika materi Logika Matematika. Pythagoras: Jurnal Pendidikan Matematika, 8(1). Retrieved from

https://journal.uny.ac.id/index.php/ pythagoras/article/view/8493

Jumasa, M. A., \& Surjono, H. D. (2016). Pengembangan multimedia pembelajaran Bahasa Inggris untuk pembelajaran teks recount di MTSN II Yogyakarta. Jurnal Inovasi Teknologi Pendidikan, 3(1), 25-39. Retrieved from https://journal.uny.ac.id/index.php/ jitp/article/view/8287

Kementerian Pendidikan dan Kebudayaan. (2016). Silabus mata pelajaran Sekolah Menengah Pertama/Madrasah Tsanawiyah (SMP/MTs): Matematika. Jakarta: Kementerian Pendidikan dan Kebudayaan.

Mardapi, D. (2008). Teknik penyusunan instrumen tes dan nontes. Yogyakarta: Mitra Cendikia Press.

Mayer, R. E. (2009). Multimedia learning (2nd ed.). New York: Cambridge University Press.

Nazalin, N., \& Muhtadi, A. (2016). Pengembangan multimedia interaktif pembelajaran kimia pada materi hidrokarbon untuk siswa kelas XI SMA. Jurnal Inovasi Teknologi Pendidikan, 3(2), 221. https:// doi.org/10.21831/jitp.v3i2.73 59

Ormrod, J. E. (2009). Psikologi pendidikan membantu siswa tumbuh dan berkembang jilid 2. (A. Kumara, Trans.) (6th ed.).
New Jersey: Prentice Hall.

Rosyidi, H. (2015). Analisis kesulitan belajar siswa kelas VIII SMP N 4 Pandak Bantul dalam menyelesaikan persoalan lingkaran. Skripsi. Unpublished. Universitas Islam Negeri Sunan Kalijaga Yogyakarta.

Sanjaya, W. (2011). Perencanaan dan desain sistem pembelajaran. Jakarta: Kencana.

Sari, D. S., \& Sugiyarto, K. H. (2015). Pengembangan multimedia berbasis masalah untuk meningkatkan motivasi belajar dan kemampuan berpikir kritis siswa. Jurnal Inovasi Pendidikan IPA, 1(2), 153. https:// doi.org/10.21831/jipi.v1i2.75 01

Siregar, E., \& Nara, H. (2014). Teori belajar dan pembelajaran. Bogor: Ghalia Indonesia.

Sukardi. (2013). Metodologi penelitian pendidikan: Kompetensi dan praktiknya. Jakarta: Bumi Aksara.

Tun'isah, I. F. (2011). Analisis kesalahan dalam menyelesaikan soal matematika pokok bahasan lingkaran pada siswa kelas VIII SMP Negeri 14 Malang. Skripsi. Unpublished. Universitas Negeri Malang.

Widyatmojo, G., \& Muhtadi, A. (2017). Pengembangan multimedia pembelajaran interaktif berbentuk game untuk menstimulasi aspek kognitif dan bahasa. Jurnal Inovasi Teknologi Pendidikan, 4(1), 38. https:// doi.org/10.21831/jitp.v4i1.10 194 